\title{
Pursuing Cross-Cultural Pedagogical Success in China
}

\author{
William E. Allen \\ Correspondence: William E. Allen, Ph.D, Pursuing Cross-cultural Pedagogical Success in China; Fort Hays State \\ University, College of Business and Entrepreneurship, 600 Park Street, Hays, KS 67601, USA.
}

Received: January 17, 2019

doi:10.11114/ijce.v2i1.4079

\author{
Accepted: February 14, 2019 Online Published: February 19, 2019 \\ URL: https://doi.org/10.11114/ijce.v2i1.4079
}

\begin{abstract}
The purpose of this article is to present issues for research consideration related to cross-cultural teaching challenges as an American in China. This article describes my pedagogical practices and insight after five years of teaching business ethics, management and leadership primarily to Chinese undergraduate students in Henan Province, Central China. The issues raised and the suggestions for future research explored herein will hopefully lead to greater understanding and pedagogical success for American teachers working in China. In addition, cross-cultural educators may gain at least one critical tool or insight to increase their teaching efficacy as all educators are teaching cross-culturally with the presence of ethnic groups and international students in classrooms. At a minimum, this discussion may shorten the learning curve a bit for those recent to the profession who find themselves in an unfamiliar cultural environment and who strive to adapt their pedagogy for improved classroom experiences and student-centered course outcomes.
\end{abstract}

Keywords: cross-cultural, management, pedagogy, China, research

\section{Introduction}

American teachers are traveling abroad in greater numbers as Chinese and other Asians become more affluent (Collier $\&$ Rosch 2016). Research on cross-cultural management and leadership has been prolific (Zimmerman, 2015) and the need for adapting to cross-cultural environments has been well established (Giddens 2003; Hofstede \& Hofstede 2005; House, Hanges, Javidan, Dorfman, \& Gupta 2004). What is lacking however, are research and outcomes specifically addressing how Americans teaching in China can find pedagogical success (Li, Rao, \& Tse 2012). As responsible educators, American teachers in cross-cultural environments must ask themselves, "Are we engaging in culturally responsive (and responsible) teaching?" (Freeman 2015). Though this question includes a consideration of what happens in the classroom, it requires a holistic approach to cross-cultural adaptation (Fall, Kelly, MacDonald, Primm, \& Holmes 2013; Ozturgut 2007). The following discussion addresses the cross-cultural challenges related to personal adaptation, classroom adaptation, and matters of academic honesty. The statements I make in this paper can be reasonably generalized to other Chinese universities based on frank conversations I have had with my students.

\subsection{Personal Development/Care}

An individual's home culture constructs the window through which the rest of the world must pass and make sense (Hofstede et al. 2005). Cross-cultural exposure unavoidably changes that frame of reference and an individual's prior dominant understanding of reality begins to adjust (Bennett 2004). Cross-cultural competence relates directly to self-discipline in a person's quest to learn about another culture (Allen 2014). Actively working toward this competence is correlated with effective cross-cultural pedagogy (Bickley, Rossiter, \& Abbott 2014).

When I first arrived in China, the inability to speak the language, the unfamiliar traditions and customs, and the lack of understanding associated with the nuances of social encounters caused me to experience a degree of culture shock. This surprised me because I had spent time in Asia before, though not in China. Culture shock manifests itself in the form of impatience, frustration, and dissatisfaction with even the smallest of challenges (Gergen 2015; Zimmerman 2015). To overcome culture shock, I took opportunities to expand my cultural exposure by experiencing smaller towns with artifacts of Chinese history and culture. A new iPhone gave me considerably more freedom and independence with map, train, and translation apps. Cross-cultural adaptation happens only with a proactive approach and that directly relates to effective teaching in the classroom (see Appendix A).

\subsection{Delivery/Pedagogy}

Teachers in Eastern cultures generally control knowledge and deliver instruction in a unidirectional process for the 
student to listen, retain, and use to pass examinations (Tang 2009). Confucian traditions honor the ability to memorize large amounts of literature with no thought given to challenging content (Wu 2011). That system contrasts with the Western approach to instruction and learning where the teacher and the student work together to achieve educational goals (Huang \& Brown 2009). As a first step toward working together with the students, I appoint a class liaison as my communication contact via the Chinese social media app WeChat. I also adapt pedagogy to engage students in ways (Socratic Method) that had not been required of them in the past. I reject the Chinese system of awarding points for attendance (10-30\% of the final grade) in lieu of points only for participation in class. I track participation and other student behavior with a seating chart. Unannounced assessment during class via phone-accessible web-based quizzes (Quizmoz.com) reveal problem areas in understanding. I also work to limit my lecture and PowerPoint (PPT) content delivery to three minutes so that students can be actively engaged in learning through Chinese case studies, short videos followed by discussion, student presentations, etc.

Students do use translator apps for real time translation as their phone scans a PPT slide or a page of text. I translate key words myself for the PPTs because a single English word may show more than twenty different Chinese characters. The final translation of technical words and concepts is constructed in the classroom as the students and I work through the material together.

Because Google, YouTube, Facebook, and Gmail are blocked in China, a Virtual Private Network (VPN) such as Strong VPN is necessary. I use subtitle translation for YouTube files via downloaders such as 4K Video Downloader to help clarify meaning. The importance of these efforts to bridge the language and cultural classroom differences cannot be overstated.

\subsection{Discipline/Academic Honesty}

American teachers in Chinese classrooms struggle with incidences of students committing academic dishonesty (La Roche 2011; Rawwas, Al-Khatib, \& Vitell 2004). Western teachers, however, should understand Eastern students' Confucian tradition of honoring prominent authors with copies of their original work (La Roche 2011). My students understand that, by the second class, they must form themselves into teams and provide me with a Team Resume including student photos, identification numbers, and contact information. Those documents help me ensure I have the enrolled student(s) in my class and at exams. I give assignments and projects unique to a student's own experience or hometown and I occasionally use in-class handwritten assignments. Plagiarism screening tools such as SafeAssign or Turnitin offer only limited safeguards because students know workarounds with consecutive Chinese and English translation applications. In addition, those plagiarism screening tools do not include Chinese-English sources such as China Daily News.

For exams, I use multiple versions of the same exam, smaller ten point font on answer sheets (T/F, ABCD, etc.), large exam rooms to separate students, and additional proctors to decrease the opportunity for cheating. I prohibit phones in the exam room because key words have been translated in class and the integrity of the exam would be compromised through Chinese social media if students had access to their phones. I avoid computer-based exams because students are seated within inches of each other and electric power in the exam rooms is occasionally unreliable, at least on my campus. Punishment for academic dishonesty ranges from a zero for the exam/assignment to referring the student(s) to a disciplinary board where course failure and/or expulsion from the school may be considered.

\section{Connection to Theory}

The sum total of the experiences and techniques for effective cross-cultural management pedagogy outlined above have enabled me to address many of the challenges acknowledged in the literature. Significant empirical gaps, however, exist and are discussed in the same order.

\subsection{Personal Development/Care}

Cross-cultural competency relates to interaction between individuals from different cultures working effectively together (Navaitiene, Racetlyte, \& Rimkeviciene 2015) and it is required of cross-cultural professionals (Goryunova \& Jenkins 2017). Having to spend time among a group of people with unknown behaviors, values, beliefs, and actions results in culture shock exemplified by frustration, confusion, uncertainty, anxiety and stress (Zimmerman 2015). Watching, listening, and asking questions build genuine relationships in a new culture and advances the cultural learning process (Deardorff 2009) through a growing understanding of words and body language (Bodycott, Mak, \& Ramburuth 2014; MacDonald \& O'Regan 2013). An individual's own expectations begin to mirror those of the host culture and those positive experiences help to minimize negative thoughts during times of stress (Seligman 2002). Cultural intelligence abilities directly correlate to successful functioning in different cultural environments and valid and reliable cultural intelligence assessments are recommended for individuals working to increase their cross-cultural competency (Deardorff 2011). An appreciation of different cultures and backgrounds through activities results in 
increased competency (White 2008) however which precise activities are the most effective has not been empirically evaluated nor have any activities been correlated with cultural intelligence scores.

\subsection{Delivery/Pedagogy}

An American teacher's failure to adapt instruction to meet the learning needs of Chinese students results in an unnecessary gap in learning (Huang 2012). Translation into the first language of English as Foreign Language (EFL) students in the classroom improves communication and comprehension (Bickley et al. 2014) and establishes a mental relationship and formal logic that can bridge cultural differences (Levinas 2012). First language use also improves EFL student conceptual learning (Simsek 2010) and may afford more accurate assessment (Bao \& Du 2015).

Case studies connect concepts and course material to the students' culture and increase understanding, participation, and academic achievement (Nieto \& Bode 2012). Chinese students are reluctant to participate in Western classroom environments (Harryba, Guilfoyle, \& Knight 2012) and they seldom raise their hand to ask or to answer a question (Huang et al. 2009; Liu 2002). Teachers that work to create a learning environment utilizing both Western and Eastern pedagogy generally excel (Tang 2009). The precise techniques that successful American teachers in China use to increase pedagogical efficacy have not been empirically identified.

\subsection{Discipline/Academic Honesty}

One of the issues American faculty in China face is how to deal with incidences of cheating and plagiarizing on tests and assignments (La Roche 2011). These challenges related to academic honesty are well supported by research noting the differences between Eastern and Western student attitudes toward cheating (Hu \& Lei 2015; James, Miller, \& Wyckoff 2017; Li 2013). For these students (Zhao \& Biesta 2011) millennia old traditions are an unrealized reality they live by that shape their lives in the form of ideals about maintaining respect, public welfare, and collective stability (Slethaug 2007). A gap exists in the literature regarding specific effective techniques for minimizing or eliminating student academic dishonesty in China.

\section{Suggestions for Future Research}

Research into cross-cultural teaching styles, student responses, and classroom teacher-student relations has been somewhat ignored by the academy and it needs to be undertaken ( $\mathrm{Li}$ et al. 2012). Based on my experiences in China, I have identified the foregoing issues and challenges and offer the following insights and suggestions for teaching practice-based research:

\subsection{Personal Development/Care}

In this article I argue that an American teaching in China cannot truly be successful in the classroom without working on personal cross-cultural competency. The increased understanding that will be gained affects all areas of the cross-cultural teaching experience. A solution oriented research agenda should consider the following strategic objectives:

- Identifying best practices for acculturation in China

- Understanding the correlation between 360 degree cultural intelligence assessments and measures of success in the classroom

- Quantifying causes and rates of American teachers in China leaving that market

- Improving the capabilities of teacher placement and recruitment organizations for Chinese openings to assist with the transition to China

\subsection{Delivery/Pedagogy}

In this article I have mentioned a number of classroom approaches and techniques to use for more effective pedagogy as an American teaching in China. I have also shared my strong impression that effective pedagogy must include at least a limited use of Chinese translation. This is supported in principle by the literature, however, empirical data is lacking. A research protocol addressing these challenges should include the following strategic objectives:

- Developing innovative tools and methodologies for successful pedagogy in China

- Identifying best practices for cross-cultural pedagogy in China

- Meeting the unique challenges of Chinese EFL students for technical language acquisition and comprehension

- Understanding the correlation between achievement of learning outcomes in Chinese classrooms where an instructor uses/provides Chinese translation for key words versus those that do not 


\subsection{Discipline/Academic Honesty}

The literature supports my contention that issues pertaining to academic honesty demand the attention of American teachers in China. Best practices however are elusive and each American educator in China must discover the challenges and responses anew. A solution oriented research agenda should consider the following strategic objectives:

- Meeting the challenge of increasingly sophisticated technology tools used for academic dishonesty in China

- Developing innovative strategies for controlling and monitoring Chinese students during exams

- Improving the capabilities of plagiarism screening tools for use in China

- Identifying best practices for promoting academic honesty amongst students in a Chinese classroom

\section{Conclusion}

The results of my methods in China discussed above have raised my student exam averages from the mid-50s to the mid-70 percentile and student course evaluations have risen from $70 \%$ "strongly agree/agree" to $88 \%$. Four years ago I was addressing incidences of academic dishonesty with approximately $25 \%$ of my students compared to the most recent academic year where I had similar conversations with approximately $2 \%$ of my students. My hope is that this discussion will encourage interest in research to identify best practices for Americans teaching in China.

\section{Compliance with Ethical Standards}

Ethical approval: This article does not contain any studies with human participants or animals performed by any of the authors.

\section{Conflict of Interest}

The author declares no conflict of interest.

\section{References}

Allen, J. F. (2014). Investigating transnational collaboration of faculty development and learning: An argument for making learning culturally relevant. International Journal for the Scholarship of Teaching and Learning, 8(2), 1-29. https://doi.org/10.20429/ijsotl.2014.080217

Bao, R., \& Du, X. (2015). Learners' L1 use in a task-based classroom: Learning Chinese as a foreign language from a sociocultural perspective. Journal of Language Teaching and Research, 6(1), 12-20. https://doi.org/10.17507/jltr.0601.02

Bennett, M. J. (2004). Becoming interculturally competent. In J.S. Wurzel (ed.) Toward multiculturalism: A reader in multicultural education. Newton, MA: Intercultural Resource Corporation.

Bickley, C., Rossiter, M., \& Abbott, M. (2014). Intercultural communicative competence: Beliefs and practices of adult English as a second language instructors. Alberta Journal of Educational Research, 60(1), 135-160. Retrieved from http://ajer.journalhosting.ucalgary.ca/index.php/ajer/article/view/1253

Bodycott, P., Mak, S. A., \& Ramburuth, P. (2014). Utilizing an internationalized curriculum to enhance students' intercultural interaction, engagement and adaptation. The Asia-Pacific Education Researcher, 23(3), 635-643. https://doi.org/10.1007/s40299-013-0136-3

Collier, D., \& Rosch, D. (2016). Effects associated with leadership program participation in international students compared to domestic students. Journal of Leadership Education, 15(4), 33-49. https://doi.org/10.12806/V15/I4/R3

Deardorff, D. K. (2009). The SAGE handbook of intercultural competence. Thousand Oaks, CA: Sage.

Deardorff, D. K. (2011). Assessing intercultural competence. New Directions for Institutional Research, 149, 65-79. https://doi.org/10.1002/ir.381

Fall, L. T., Kelly, S., MacDonald, P., Primm, C., \& Holmes, W. (2013). Intercultural communication apprehension and emotional intelligence in higher education: Preparing business students for career success. Business Communication Quarterly, 76(4), 412-426. https://doi.org/10.1177/1080569913501861

Freeman, B. (2015). A western professor in Singapore; Cross-cultural readings, expectations, and surprises in the classroom. Journal of Research in International Education, 14(2), 127-140. https://doi.org/10.1177/1475240915593842

Gergen, K. J. (2015). An invitation to social construction. London, UK: Sage. https://doi.org/10.4135/9781473921276

Giddens, A. (2003). Runaway world: How globalization is reshaping our lives. New York: Routledge. 
Goryunova, E., \& Jenkins, D. M. (2017). Global leadership education: Upping the game. Journal of Leadership Education, 16(4), 76-93. https://doi.org/10.12806/V16/I4/A1

Harryba, S. A., Guilfoyle, A. M., \& Knight, S. A. (2012). Intercultural interactions: Understanding the perspectives of university staff members, international and domestic students. International Journal of Learning, 18(12).

Retrieved from http://www.ijlter.org/

Hofstede, G., \& Hofstede, G. J. (2005). Cultures and organizations: Software of the mind. New York: McGraw-Hill.

House, R. J., Hanges, P. J., Javidan, M., Dorfman, P. W., \& Gupta, V. (Eds.). (2004). Culture, leadership, and organizations: The GLOBE study of 62 societies. Thousand Oaks, CA: Sage.

Hu, G., \& Lei, J. (2015). Chinese university students' perceptions of plagiarism. Ethics \& Behavior, 25(3), 233-255. https://doi.org/10.1080/10508422.2014.923313

Huang, J., \& Brown, K. (2009). Cultural factors affecting Chinese ESL students' academic learning. Education, 129(4), 643-653. Retrieved from https://www.questia.com/library/journal/1G1-201209730/cultural-factorsaffecting-chinese-esl-students-academic

Huang, Y. (2012). Transitioning challenges faced by Chinese graduate students. Adult Learning, 23(3), 138-147. https://doi.org/10.1177/1045159512452861

James, M., Miller, G., \& Wyckoff, T. (2017). Comprehending the cultural causes of English writing plagiarism in Chinese students at a Western-style university. Journal of Business Ethics, 140(1), 1-12. https://doi.org/10.1007/s10551-017-3441-6

La Roche, C. (2011). Looking East: Yin and yang of an academic exchange. Journal of International Education Research (JIER), 7(2), 47-54. https://doi.org/10.19030/jier.v7i2.4249

Levinas, E. (2012). Totality and infinity: An essay on exteriority ( $2^{\text {nd }}$ ed.). Upper Saddle River, NJ: Pearson Education, Inc.

Li, H., Rao, N., \& Tse, S. K. (2012). Adapting Western pedagogies for Chinese literacy instruction: Case studies of Hong Kong, Shenzhen, and Singapore preschools. Early Education and Development, 23, 603-621. https://doi.org/10.1080/10409289.2010.536441

Li, Y. (2013). Text-based plagiarism in scientific writing: What Chinese supervisors think about copying and how to reduce it in students' writing. Science and Engineering Ethics, 19(2), 569-583. https://doi.org/10.1007/s11948-011-9342-7

Liu, J. (2002). Negotiating silence in American classrooms: Three Chinese cases. Language and Intercultural Communication, 2(1), 37-54. https://doi.org/10.1080/14708470208668074

MacDonald, M., \& O’Regan, J. (2013). The ethics of intercultural communication. Educational Philosophy and Theory, 45(10), 1005-1017. https://doi.org/10.1111/j.1469-5812.2011.00833.x

Navaitiene, J., Racetlyte, D., \& Rimkeviciene, V. (2015). Adaptation of handbook for development of intercultural competence: The experiences. Pedagogy, 119(3), 33-44. https://doi.org/10.15823/p.2015.021

Nieto, S., \& Bode, P. (2012). Affirming diversity: The sociopolitical context of multicultural education (6th ed.). Boston, MA: Pearson Education, Inc.

Ozturgut, O. (2007). Teaching West in the East: An American university in China. International Journal of Teaching and Learning in Higher Education, 19(3), 228-237. Retrieved from http://www.isetl.org/ijtlhe/

Rawwas, M. Y., Al-Khatib, J. A., \& Vitell, S. J. (2004). Academic dishonesty; A cross-cultural comparison of U.S. and Chinese marketing students. Journal of Marketing Education, 26(1), 89-100. https://doi.org/10.1177/0273475303262354

Seligman, M. E. (2002). Authentic happiness: Using the new positive psychology to realize your potential for lasting fulfillment. New York, NY: Free Press.

Simsek, M. (2010). The effects of L1 use in the teaching of L2: Grammar concepts on the students' achievement. Journal of Theory and Practice in Education, 6(2), 142-169. Retrieved from http://eku.comu.edu.tr/index/6/2/mrsimsek.pdf

Slethaug, G. E. (2007). Teaching abroad: International education and the cross-cultural classroom. Hong Kong: University Press.

Tang, E. (2009). A cultural framework of "Chinese learn English": A critical review of and reflections on research. 
Journal of English as an International Language, 4, 7-43. Retrieved from http://www.eilj.com/

White, S. R. (2008). Multicultural visions of globalization: Constructing educational perspectives from the East and the West interchange. A Quarterly Review of Education, 39(1), 95-117. https://doi.org/10.1007/s10780-008-9042-7

$\mathrm{Wu}$, Z. (2011). Interpretation, autonomy, and transformation: Chinese pedagogic discourse in a cross-cultural perspective. Journal of Curriculum Studies, 43(5), 569-590. https://doi.org/10.1080/00220272.2011.577812

Zhao, K., \& Biesta, G. (2011). Lifelong learning between "East" and "West": Confucianism and the reflexive project of the self. Interchange, 42(1), 1-20. https://doi.org/10.1007/s10780-011-9143-6

Zimmerman, J. (2015). Lessons from abroad: Teaching cultural and global leadership in the U.S. classroom. Journal of Leadership Education, 14(4), 114-125. https://doi.org/10.12806/V14/I4/A2

\section{Appendix A}

\section{Teaching in China - Suggestions}

\section{Personal development/Care}

- Commiserate with colleagues, shorten the learning curve, accept help

- Actively research culture - https://www.youtube.com/watch?v=Tzx8ZJrFltU

- Appreciate the challenges for EFL students (up to one hour/page for translation and comprehension)

- Learn about students' lives, hometown, time commitments, class load, background, etc.

- Covey - habits, https://www.youtube.com/watch?v=nReHulVvIJA

- Know Chinese government restrictions, be respectful of the host country

- Attend school functions, be/get involved

- Adapt - air pollution, phones, transportation, healthcare, networks, etc.

- Get out - experience other settings, i.e., orphanages, schools, factories, etc.

- Keep in touch with people back home - but, they will never fully understand

- Attitude is a choice - https://www.youtube.com/watch?v=cRMogDrHnMQ

- Change perspectives - volunteer as a faculty representative for student organizations

- Cross-cultural assessments - https://blog.culturaldetective.com/2017/08/10/freebies3/

- Sharpen skills - https://www.youtube.com/watch?v=vdXk8Cu4Qm0

- Smile, be kind, be gentle, be genuine

\section{Delivery/Pedagogy}

- Initial case study question to focus attention - hypothetical from host culture

- Case studies - from local/current/international events

- 3 minute rule, use many different teaching modes

- $1^{\text {st }}$ language use on PPTs for key words - https://www.bing.com/translator

- Use student translators, video subtitles

- Connect local culture/heroes/villains to concepts (>4,000 years of Chinese history)

- Use of images - note Chinese emphasis on visual learning

- Socratic method to answer questions - they will get used to it

- Gather feedback - Quizmoz.com, etc.

- Activities - https://www.ted.com/talks/tom_wujec_build_a_tower

- First language TED talks - https://www.ted.com

- Use host culture websites (weibo.com, tudou.com, etc. - ask students)

- Classrooms: 
- Control classroom temperature, chairs, cleanliness, etc.

○ Early arrival for tech check, have a Plan B

○ Seating chart/point tracking, group ID

- Control student phone use - for translation assistance only

- Continual teacher movement, microphone use as needed

- Appoint/determine ID of student class liaison - responsible for communication

○ Require team resumes

○ Points - unannounced quizzes, in-class assignments, etc.

○ Be wise, i.e., excuses for absences

○ Explain classroom rules - Eastern teachers' rules differ!

○ Adjust PPTs for poor student vision - font $>44$ when possible

\section{Discipline/Academic honesty}

- Pause, listen before speaking, ask questions, be slow to judge, do not jump to conclusions

- Address cheating, hold accountable, provide private opportunity to confess

- Construct exams/room environment to eliminate opportunities for cheating

- Use tools - Turnitin.com, http://www.blackboard.com/safeassign/index.html, etc.

- Hand written papers, unique to own experience or hometown - in-class work

- Be understanding - talking in class may be one student explaining to another

- Be understanding - https://www.youtube.com/watch?v=4icmvt7BjSs

- Self-educate - https://www.youtube.com/watch?v=4zHJMAoDOqU

\section{Copyrights}

Copyright for this article is retained by the author(s), with first publication rights granted to the journal.

This is an open-access article distributed under the terms and conditions of the Creative Commons Attribution license which permits unrestricted use, distribution, and reproduction in any medium, provided the original work is properly cited. 